\title{
Statistical Application of Regression techniques in Modeling Road Accidents in Edo State, Nigeria
}

Guobadia Emwinloghosa Kenneth ${ }^{1}$, $^{*}$

${ }^{1}$ Department of Administration, Federal Medical Centre, Asaba, Delta State, Nigeria

${ }^{2}$ Department of Statistics, University of Benin, Benin, Nigeria

DOI: $10.36347 /$ sipms.2021.v08i01.003 $\quad$ | Received: 08.01.2021 | Accepted: 18.01.2021 | Published: 20.01 .2021

*Corresponding author: Guobadia Emwinloghosa Kenneth

Abstract

Original Research Article

Road traffic crashes in Edo State Nigeria was considered in this paper, secondary data were mainly used, and was sourced from the office of the Federal Road Safety Corps; Policy, Research and Statistics Department RSHQ Abuja. In order to determine how well a set of independent variables (Mechanical Fault, Reckless Driving and Over-Loading) can predict road accidents in the state of Edo, Regression Analysis was used, indicating the best road accident predictor in the state. The results show that the assumptions of Normality, Homoscedasticity, Freedom, Linearity, Multicollinearity and Outliers are not violated. The three predictors significantly predicted $\operatorname{road}$ accident $\{\mathrm{F}(3,9)=$ 14.132 , p-value $=0.001<0.005\}, \mathrm{R}_{\text {adjusted }}^{2} 0.767 ; 76.7 \%$, of the total variance in road accident cases was explained by the model, Mechanical Fault made the strongest unique significant contribution to explaining road accident cases when the variance explained by all other variables in the model is controlled for ( $\beta$ eta value $=0.841, p$-value $=0.001$ ), Reckless driving made less of a contribution ( $\beta$ eta value $=0.591, \mathrm{p}$-value $=0.004$ ), while overloading did not make a significant contribution to the prediction of road accident when the variance explained by other variables in the model is controlled for $(\beta$ eta value $=0.173, \mathrm{p}$-value $=0.228)$. The developed prediction model is; Number of Road Accident $=6.407+1.300$ Reckless Driving +1.959 Mechanical Fault +0.733 Overloading .

Keywords: Road Traffic Crashes, Reckless Driving, Mechanical Fault, Overloading, Regression Approach.

Copyright $(\mathcal{O} 2021$ The Author(s): This is an open-access article distributed under the terms of the Creative Commons Attribution 4.0 International License (CC BY-NC 4.0) which permits unrestricted use, distribution, and reproduction in any medium for non-commercial use provided the original author and source are credited.

\section{INTRODUCTION}

Deaths from road accidents in Nigeria have been ranked among the highest in the world [1]. Accidents may occur at any level of traffic, however, based on the speed at which they occur, the fatality of these accidents varies. The death toll resulting from road traffic collisions increased from $38.9 \%$ in 1967 to $58 \%$ in 1974 [1]. In order to mitigate the mortality, car collisions have reached an unbearable degree that road accidents must be attacked with all severity. Since 1913, with the creation of the Federal Road Safety Corps (FRSC) in an attempt to combat road accidents in Nigeria, several attempts have been made by the government [1]. The FRSC has been tasked with ensuring the safety of roads in Nigeria. At such flash points, such as when there are sharp curves, potholes and poor parts of the highways, road accidents tend to occur occasionally. At such points, it is typically difficult for speeding drivers to control their cars, which then results in fatal traffic accidents, especially at night [2]. Cases of fatal road accidents on major highways in the state of Edo are registered almost daily. These fatal road traffic accidents in the state often include different types of vehicular traffic. Analysis in this field has concentrated on road traffic accident incidents, compilation of data on road traffic accidents and road safety initiative impact evaluation [3-7]. Study in this sector at the local level focuses on the impact of land use and human factors on road injuries [8-10]. Without the occurrence of a road traffic accident in Nigeria today, hardly a day goes by leading to a generally rising incidence of morbidity and mortality rates as well as financial costs for both society and the person involved. Information about some of these traffic incidents gets to the media houses' news rooms and is broadcast while most go unreported. As well as the largest number of deaths per 10,000 vehicles, Nigeria has the highest road accident rate [11]. One may be tempted to believe that the level of awareness among Nigerians about the causes of road traffic accidents is very low. Nigerian highways, put differently, have become killing fields for their users without security. If they build their 
Guobadia Emwinloghosa Kenneth., Sch J Phys Math Stat, Jan, 2021; 8(1): 14-18

destinations, travelers heave a sigh of relief [12]. Previous research has shown that Nigerians know quite a lot about what could cause road traffic accidents, contrary to the common perception that Nigerians have a very low level of knowledge about the causes of road traffic accidents [13]. Nigeria has the status of a developing country where road facilities are grossly insufficient for the abundant population of road users to transport. The discovery of oil in Nigeria came with its own problems. Prior to the 'Oil boom' in Nigeria, road accidents were rather rare. The oil boom brought with it an increase in people's disposable income, which in turn increased ownership of vehicles and caused 'rapid' industrialization. This undoubtedly calls for improved accessibility of the road network. Therefore, roads were constructed, but without dire attention to standard. Adequate measures and supervision have not suited these innovations [11]. Consequently, for Nigerian people and road users, the roads have become a death trap. This is necessary if it is possible to avoid the majority of these accidents and deaths. The fact that the occurrence is growing becomes worrisome [12]. Successful measures include the construction of safer roads and the integration into land use and transport planning of road safety features; enhancing the safety characteristics of vehicles [13-15]. To a very large degree, it is not entirely the bad deplorable state of Nigerian roads that causes incessant road traffic accidents, but the carelessness and incompetence of its road users can be attributed to a large proportion. Therefore, the primary objective of the analysis is to evaluate how well "Mechanical Fault", "Reckless Driving" and "Over-Loading" can predict "Road Accident" in Edo State, suggesting that the best road accident predictor in the state is able to predict a significant amount of the variance in Road Accident when Mechanical Fault and Reckless Driving are adjusted for and if Overloading is still able to predict a significant amount of the variance in Road Accident [14].

\section{METHODOLOGY}

To achieve the set objectives, some models were reviewed and applied which includes;

\section{Multiple Linear Regression Model}

Was used to determine how well a set of explanatory variables (mechanical fault, reckless driving, and over loading) is able to predict the response variable (number of road accident), which variable in the set of explanatory variables is the best predictor of road accident and whether an explanatory variable is still able to predict the response variable when the effect of another explanatory variable are controlled for [16-18].

$$
\begin{aligned}
& Y=x \beta+e_{i} \\
& Y=\beta_{0}+\beta_{1} x_{1}+\beta_{2} x_{2}+\ldots+e_{i}
\end{aligned}
$$

Where $\mathrm{i}=1,2, \ldots, \mathrm{n}$

$\mathrm{Y}$ is the Outcome Variable

$\beta_{0}, \beta_{1}, \ldots, \beta_{\mathrm{n}}$ are the parameters of the model

$\mathrm{x}_{1}, \mathrm{x}_{2}, \ldots, \mathrm{x}_{\mathrm{n}}$ are the predictors

$$
\begin{aligned}
& \text { Estimation of Model Parameters } \\
& Y=x \beta+e_{i} \\
& e_{i}=Y-x \beta \\
& e^{i} e^{i}=(Y-x \beta)^{2}=(Y-x \beta)^{\prime}(Y-x \beta) \\
& e^{i} e=Y^{\prime} Y-Y^{\prime} X \beta-X^{\prime} Y \beta+X^{\prime} X \beta^{2} \\
& e^{i} e=Y^{\prime} Y-2 X^{\prime} Y \beta+X^{\prime} X \beta^{2} \\
& \Sigma\left(e^{i} e\right)=\Sigma\left(Y^{\prime} Y-2 X^{\prime} Y \beta+X^{\prime} X \beta^{2}\right) \\
& \Sigma \delta\left(e^{i} e\right) / \delta \beta=-2 X^{\prime} Y+2 X^{\prime} X \beta=0 \\
& :-2 X^{\prime} X \beta=2 X^{\prime} Y \\
& X^{\prime} X \beta=X^{\prime} Y \\
& \beta=\left(X^{\prime} X\right)^{-1} X^{\prime} Y
\end{aligned}
$$

\section{RESULTS AND DISCUSSION}

Table-1: Describing Facts about the Variables (Descriptive Statistics)

\begin{tabular}{|l|l|l|l|}
\hline Descriptive Statistics & Mean & Std. Deviation & $\mathrm{N}$ \\
\hline & 39.83 & 5.044 & 18 \\
\hline Road Accident & 9.44 & 2.431 & 18 \\
\hline Reckless Driving & 10.33 & 2.401 & 18 \\
\hline Mechanical Fault & 2.06 & 1.259 & 18 \\
\hline Over Loading &
\end{tabular}

Table-2: Relationship between the Variables (Correlation)

\begin{tabular}{|l|l|l|l|l|l|}
\hline & & $\begin{array}{l}\text { ROAD } \\
\text { ACCIDENT }\end{array}$ & $\begin{array}{l}\text { RECKLESS } \\
\text { DRIVING }\end{array}$ & $\begin{array}{l}\text { MECHANICAL } \\
\text { FAULT }\end{array}$ & $\begin{array}{l}\text { OVER } \\
\text { LOADING }\end{array}$ \\
\hline \multirow{3}{*}{$\begin{array}{l}\text { Pearson } \\
\text { Correlation }\end{array}$} & ROAD ACCIDENT & 1.000 & .347 & .636 & .372 \\
\cline { 2 - 6 } & RECKLESS DRIVING & .347 & 1.000 & .178 & .220 \\
\cline { 2 - 6 } & MECHANICAL FAULT & .636 & -.178 & 1.000 & .344 \\
\cline { 2 - 6 } & OVER LOADING & .372 & .220 & .344 & 1.000 \\
\hline \multirow{5}{*}{ Sig. (1-tailed) } & ROAD ACCIDENT &. & .079 & .002 & .064 \\
\cline { 2 - 6 } & RECKLESS DRIVING & .079 &. & .240 & .190 \\
\cline { 2 - 6 } & MECHANICAL FAULT & .002 & .240 &. & .081 \\
\cline { 2 - 6 } & OVER LOADING & .064 & .190 & .081 &. \\
\hline $\mathrm{N}$ & ROAD ACCIDENT & 18 & 18 & 18 & 18 \\
\hline & RECKLESS DRIVING & 18 & 18 & 18 & 18 \\
\cline { 2 - 6 } & MECHANICAL FAULT & 18 & 18 & 18 & 18 \\
\cline { 2 - 6 } & OVER LOADING & 18 & 18 & 18 & 18 \\
\hline
\end{tabular}


Table-3: Tests of Normality

\begin{tabular}{|l|l|l|l|l|l|l|}
\hline & \multicolumn{3}{|c|}{ Kolmogorov-Smirnov } & \multicolumn{3}{|l|}{ Shapiro-Wilk } \\
\hline & Statistic & Df & Sig. & Statistic & df & Sig. \\
\hline ROAD ACCIDENT & .177 & 18 & .142 & .920 & 18 & .130 \\
\hline RECKLESS DRIVING & .184 & 18 & .111 & .926 & 18 & .165 \\
\hline MECHANICAL FAULT & .113 & 18 & $.200^{*}$ & .944 & 18 & .340 \\
\hline OVER LOADING & .299 & 18 & .000 & .759 & 18 & .059 \\
\hline
\end{tabular}

Table-4: Extreme Values (Outliers)

\begin{tabular}{|c|c|c|c|c|}
\hline & & & Case Number & Value \\
\hline \multirow[t]{10}{*}{ Mahalanobis Distance } & \multirow[t]{5}{*}{ Highest } & 1 & 3 & 6.96580 \\
\hline & & 2 & 15 & 5.13626 \\
\hline & & 3 & 9 & 5.11165 \\
\hline & & 4 & 5 & 4.67143 \\
\hline & & 5 & 7 & $3.83288^{\mathrm{a}}$ \\
\hline & \multirow[t]{5}{*}{ Lowest } & 1 & 16 & .40219 \\
\hline & & 2 & 1 & .85861 \\
\hline & & 3 & 2 & .95270 \\
\hline & & 4 & 6 & .96624 \\
\hline & & 5 & 8 & 1.31107 \\
\hline
\end{tabular}

a. Only a partial list of cases with the value 3.83288 are shown in the table of upper extremes.

Critical $\mathrm{X}^{2}$ value at an alpha level of 0.001 using the number of independent variables as degree of freEdom

Table-4b: Tabachnic and Fidell 2001 Table

\begin{tabular}{|l|l|l|l|l|l|}
\hline $\begin{array}{l}\text { No. of Independent } \\
\text { Variables }\end{array}$ & $\begin{array}{l}\text { Critical } \\
\text { Value }\end{array}$ & $\begin{array}{l}\text { No. of Independent } \\
\text { Variables }\end{array}$ & $\begin{array}{l}\text { Critical } \\
\text { Value }\end{array}$ & $\begin{array}{l}\text { No. of Independent } \\
\text { Variables }\end{array}$ & $\begin{array}{l}\text { Critical } \\
\text { Value }\end{array}$ \\
\hline 2 & 13.82 & 4 & 18.47 & 6 & 22.46 \\
\hline 3 & 16.27 & 5 & 20.52 & 7 & 24.32 \\
\hline
\end{tabular}

Source: Extracted and adapted from a table in Tabachnic and Fidell; originally from Pearson, E.S. and Hartley, H.O (Eds)

1958. Biomerika tables for statisticians (vol. 1, 2nd Edition). New York: Cambridge University Press.

Table-5: Test of Homogeneity of Variances

\begin{tabular}{|l|l|l|l|}
\hline Levene Statistic & df1 & df2 & Sig. \\
\hline 1.731 & 4 & 9 & .227 \\
\hline
\end{tabular}

Table-6: Model Summary

\begin{tabular}{|l|l|l|l|l|l|}
\hline Model & R & R Square & Adjusted R Square & Std. Error of the Estimate & Durbin-Watson \\
\hline 1 & $.908^{\text {a }}$ & .825 & .767 & 2.699 & 1.816 \\
\hline \multicolumn{5}{|l|}{ a. Predictors: (Constant), Overloading, Reckless Driving, Mechanical Fault } \\
\hline \multicolumn{2}{|l}{ b. Dependent Variable: Number of Road Accident } \\
\hline
\end{tabular}

Table-7: ANOVA

\begin{tabular}{|c|c|c|c|c|c|c|}
\hline \multicolumn{2}{|c|}{ Model } & Sum of Squares & Df & Mean Square & $\mathbf{F}$ & Sig. \\
\hline \multirow[t]{3}{*}{1} & Regression & 308.762 & 3 & 102.921 & 14.132 & $.001^{\mathrm{a}}$ \\
\hline & Residual & 65.546 & 9 & 7.283 & & \\
\hline & Total & 374.308 & 12 & & & \\
\hline \multicolumn{6}{|c|}{ a. Predictors: (Constant), Overloading, Reckless Driving, Mechanical Fault } & \\
\hline \multicolumn{6}{|c|}{\begin{tabular}{|l|l} 
b. Dependent Variable: Number of Road Accident & \\
\end{tabular}} & \\
\hline
\end{tabular}

Table-8: Coefficients

\begin{tabular}{|c|c|c|c|c|c|c|c|c|c|c|c|c|}
\hline \multirow{2}{*}{\multicolumn{2}{|c|}{ Model }} & \multicolumn{2}{|c|}{$\begin{array}{l}\text { Unstandardized } \\
\text { Coefficients }\end{array}$} & $\begin{array}{l}\text { Standardized } \\
\text { Coefficients }\end{array}$ & \multirow[t]{3}{*}{$\mathbf{T}$} & \multirow{3}{*}{$\begin{array}{l}\text { Sig. } \\
1.146 \\
\end{array}$} & \multicolumn{4}{|c|}{ Correlations } & \multicolumn{2}{|c|}{$\begin{array}{l}\text { Collinearity } \\
\text { Statistics }\end{array}$} \\
\hline & & \multirow{2}{*}{$\begin{array}{l}\text { B } \\
6.407 \\
\end{array}$} & \multirow{2}{*}{\begin{tabular}{|l|} 
Std. \\
Error
\end{tabular}} & \multirow[t]{2}{*}{ Beta } & & & \multirow{2}{*}{\begin{tabular}{|l|}
$\begin{array}{l}\text { Zero- } \\
\text { order }\end{array}$ \\
281
\end{tabular}} & \multirow[t]{2}{*}{ Partial } & \multicolumn{2}{|c|}{ Part } & \multirow[t]{2}{*}{ Tolerance } & \multirow[t]{2}{*}{ VIF } \\
\hline 1 & (Constant) & & & & & & & & & & & \\
\hline & Reckless Driving & 1.300 & .332 & .591 & & 3.920 & .004 & .233 & .794 & .547 & .857 & 1.167 \\
\hline & Mechanical Fault & 1.959 & .410 & .841 & & 4.777 & .001 & .715 & .847 & .666 & .628 & 1.591 \\
\hline & Overloading & .733 & .710 & .173 & & 1.033 & .328 & .500 & .326 & .144 & .691 & 1.447 \\
\hline
\end{tabular}

Number of Road Accident $=6.407+1.300$ Reckless Driving + 1.959Mechanical Fault + 0.733Overloading 


\section{Dependent Variable: ROAD ACCIDENT}

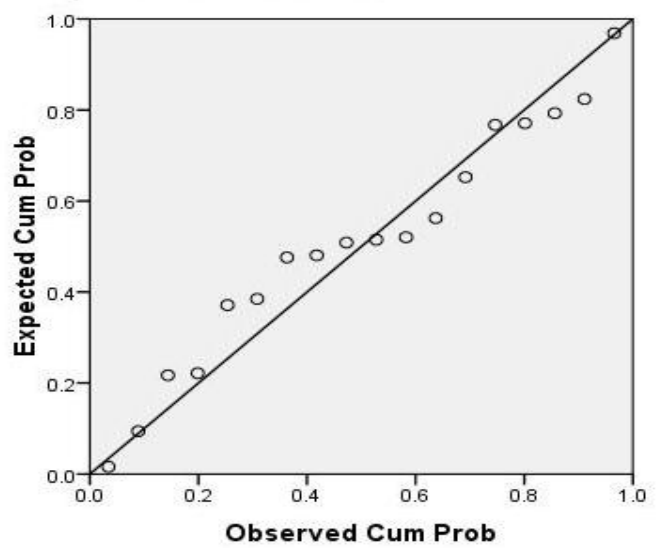

Fig-1: Normal P-P Plot of Regression Standardize Residual

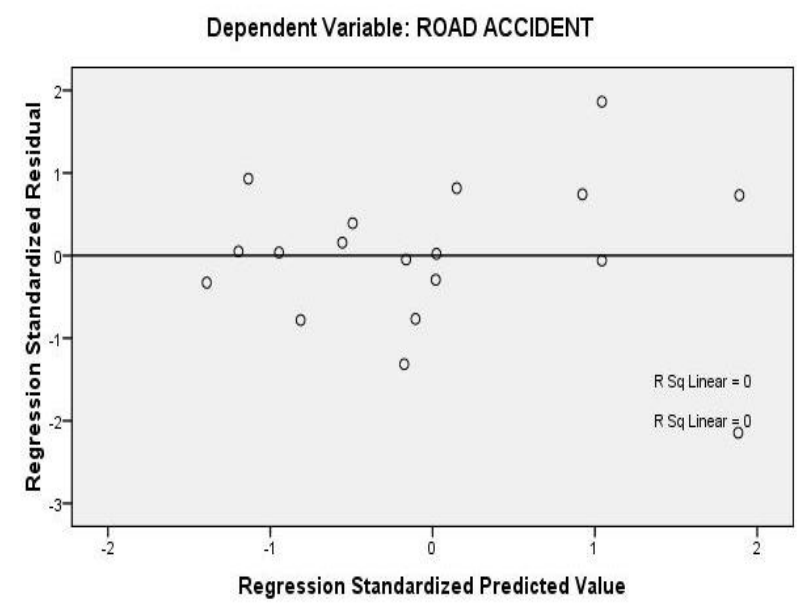

Fig-2: Scatterplot

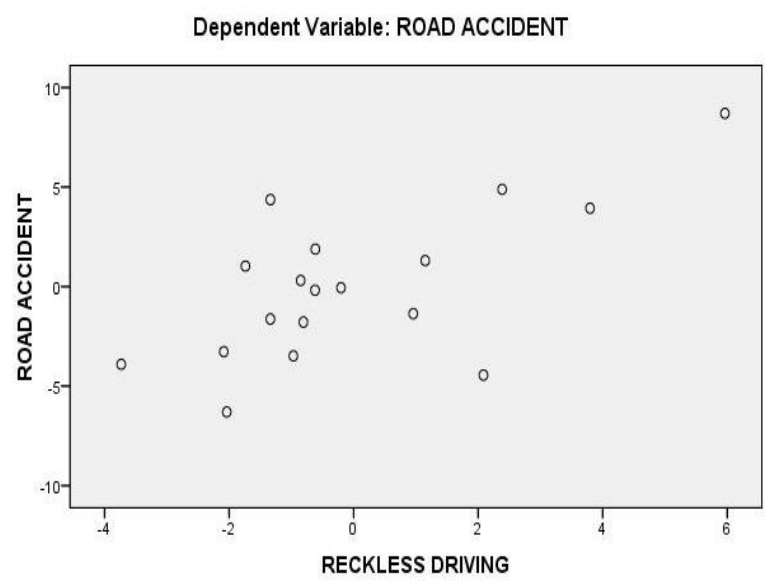

Partial Regression Plot

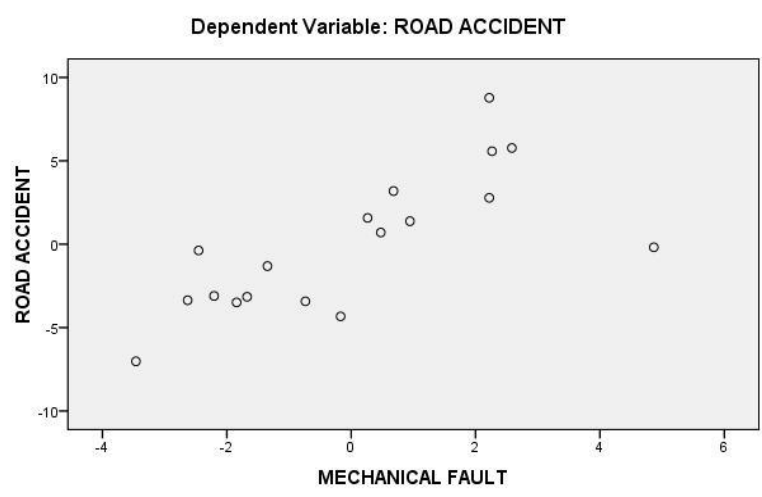

Partial Regression Plot

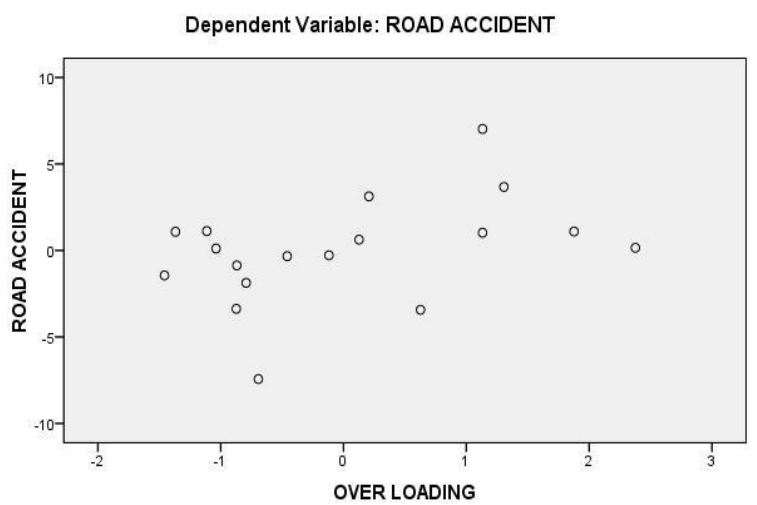

Fig-3: Partial Regression Plot

Regression Analysis was performed on the data to find out how well "Mechanical Fault", "Reckless Driving" and "Over-Loading" is able to predict "Road Accident" in Edo State, indicating, the best predictor of Road Accident in Edo State and to know if Overloading is still able to predict a significant amount of the variance in Road Accident when Mechanical Fault and Reckless Driving is controlled for, the data showed no violation to the assumptions of Normality \{(From Visual Inspection of the Normal P-P Plot of Regression Standard Residual) and from Shapiro-wilk p-values (Pvalue for Road Accident $=0.130, \mathrm{p}$-value for reckless driving $=0.165, \mathrm{p}$-value for Mechanical Fault $=0.340$, p-value for Over loading $=0.059)\}$, Homogeneity of variance (From Visual Inspection of the Scattered Plot of Regression Standard Residual against Regression Standardize predicted value also from Levene's Statistic $=1.731$, p-value $=0.227>0.05)$, Independence ( Durbin-Watson statistic $=1.816>1.5)$, Linearity (Visual Inspection of the Regression Partial Plots), Multi-Collinearity (Tolerance $>0.1$, Variance Inflator Factor < 10, $\mathrm{r}$ (between the independent variables) < 0.7), Outliers (Mahalanobis Distance $<\mathrm{X}_{0.001,3}^{2}=$ 16.27). The analysis Show that the three predictors (Reckless driving, Mechanical Fault and Over loading) 
Guobadia Emwinloghosa Kenneth., Sch J Phys Math Stat, Jan, 2021; 8(1): 14-18

statistically significantly predicted road Accident, $\mathrm{F}(3,9)=14.132, \mathrm{p}$-value $=0.001<0.005, \mathrm{R}_{\text {adjusted }}^{2}=$ $0.767 ; 76.7 \%$ of the total variance in Road Accident is explained by the model. Mechanical When the variance explained by all other variables in the model is accounted for $(\beta$ eta value $=0.841, \mathrm{p}$-value $=0.001$ ), Careless Driving made a lower contribution ( $\beta$ eta value $=0.591, \mathrm{p}$-value $=0.004$ ), while Overloading did not make a significant specific contribution to the Road Acci prediction, Fault made the strongest statistically unique significant contribution to explaining Road Accident.

\section{CONCLUSION}

The three predictors (Reckless driving, Mechanical Fault and Over loading) statistically significantly predicted road Accident, as $76.7 \%$ of the total variance in Road Accident was explained by the model. Mechanical Fault made the Strongest statistically unique significant contribution to explaining Road Accident when the variance explained by all other variables in the model is controlled for, Reckless Driving made a less of a contribution while Overloading did not make a significant unique contribution to the prediction of Road Accident when the variance explained by all other variables in the model is controlled for. Therefore, the Government of Edo State should organize seminars, lectures and talkshows enlightening Motorists on Engine maintenance, the importance of checking their Carburetor water gauge, engine oils, break fluid e.t.c. At the same time enlightening them on how to use the Highway and the dangers of reckless driving. The Government should also set up Government Owned Driving Colleges to tutor both the theoretical and practical usage of Vehicle, and issues driver's license and/or vehicle permit only to graduates from such colleges, as this would greatly reduce the production of unprofessional drivers in the state, hence reducing road accident. Finally, Government should construct more pedestrian bridges to avoid pedestrians crossing the highway as this would greatly reduce accident cases in the state.

\section{REFERENCES}

1. Adeniyi A., (1985), "Provision of Mass Transit in Nigerian Cities", -Transportation in Nigerian for national development, Federal Road Safety Corps, Nigeria.

2. Asalor, J. O. (2010). Towards Improved Road Safety in Nigeria. Technical Report No. Rts/00/82/011, Faculty of Engineering, University of Benin.

3. Osuji G.A., Obubu, M., Obiora-Ilouno H.O (2016). Uterine Fibroid on Women's Fertility and Pregnancy Outcome in Delta State, Nigeria. Journal of Natural Sciences Research. 6(2):27-33.

4. Obubu, M., Konwe C.S., Nwabenu D.C., Omokri Peter A., Chijoke M. (2016) Evaluation of the
Contribution of Nigerian Stock Market on Economic Growth; Regression Approach. European Journal of Statistics and Probability. 4(5):11-27

5. Atubi, A.O. (2009b) "Urban Transportation: An Appraisal of Features and Problems in the Nigerian Society". International Journal of Geography and Regional Planning. Vol. 1, No. 1, Pp. 58-62.

6. Backer, W. (1996) "Impact Assessment of Road Safety Campaign” Transportation Review. 16 (4): 345-355.

7. Central Bank of Nigeria (1997) Annual Report and Statement of Account for the Year Ended 31st December, CBN, Abuja.

8. Osuji, G.A., Okoro, C.N., Obubu, M., ObioraIlouno H.O. (2016). Effect of Akaike Information Criterion on Model Selection in Analyzing AutoCrash Variables. International Journal of Sciences: Basic and Applied Research. 26(1):98-109.

9. Eze, B (2012) Road Traffic Accidents in Nigeria: A Public Health Problem.

10. Gozias, J.C.; Matsouki, E.C. and Yannis, G.D. (1997) "An Analysis of Factors Affecting Road Safety: The Greek Experience" Journal of Transportation Geography 5 (3): 325-316.

11. Odero, W. Khayes, I.M. Meda, P. M. (2003) Road Traffic Accident in Kenya: Magnitude, Causes and Status of Intervention. Injury Control and Safety Promotion, 10, Pp. 53-61.

12. OECD, (1994) Managing the Environment: the Role of Economic Instrument. Paris.

13. Ogunjumo, A. (1995) En Evaluation of Nigerian Airways' and Foreign Management Consultants' domestic Operations: 1974-1986: The Nigerian Journal of Economic and Social Studies, Pp. 34 (1).

14. Obubu Maxwell, Babalola A. Mayowa, Ikediuwa U. Chinedu, Amadi Peace (2018). Modeling Count Data; a Generalized Linear Model Framework. American Journal of Mathematics and Statistics. 8(6): 179-183 doi:10.5923/j.ajms.20180806.03.

15. Onokala, P.C. (1995) The Effect of Land use on Road Traffic Accident in Benin-City, Nigeria. Journal of Transport Studies, Vol. 1, No. 1, Pp. 34 44.

16. Omojola, A.S.(2004) "Transport and Communication" in Kayode, M.O. and Usman, Y.B. (eds) Nigeria since Independence. Vol. 2, Ibadan; Heinemann. Pp. 132-152.

17. Sheriff, M. A. (2009). Traffic Education and Safety in Nigeria, Nitours Journal Vol. II, Kano.

18. Obubu, M., Konwe C.S., Nwabenu D.C., Omokri Peter A., Chijoke M. (2016) Empirical Analysis on Road Traffic Crashes in Anambra State, Nigeria; Accident Prediction Modeling using Regression Approach. European Journal of Statistics and Probability. 4(4):18-27 